\title{
MEDIA PEMBELAJARAN M3 (MEMBACA, MENULIS, MENGHITUNG) BERBASIS MULTIMEDIA UNTUK ANAK USIA DINI
}

\author{
Muh. Fahrurrozi ${ }^{1}$,Lalu Puji Indra Kharisma ${ }^{2}$, Khairunnazi $^{3)}$ \\ ${ }^{1,2,3)}$ STMIK Syaikh Zainuddin NW Anjani NTB \\ e-mail: f4.rozi@gmail.com ${ }^{1)}$, $\underline{\text { alupujii@gmail.com }}^{2)}, \underline{\text { m4sterlenk@gmail.com }}^{3)}$
}

\begin{abstract}
ABSTRAK
Pendidikan Taman Kanak-Kanak (TK) merupakan salah satu bentuk Pendidikan anak usia dini yaitu anak yang berusia empat sampai dengan enam tahun. Tujuan pendidikan TK untuk meletakkan dasar ke arah perkembangan sikap, pengetahuan, keterampilan dan daya cipta yang diperlukan anak untuk menyesuaikan diri dengan lingkungan dan perkembangan selanjutnya menjadi sekolah baca tulis hitung. Untuk mengembangkan kemampuan dasar anak usia dini dalam baca hitung diperlukan metode yang menarik dan membuat anak tertarik untuk belajar, begitu banyak buku yang tersedia di toko buku dengan berbagai warna dan bentuk yang menarik, namun terkadang mereka juga butuh mendengar bagaimana cara mengucapkan dan mendengar yang mereka pelajari secara mandiri. Untuk mengembangkan minat mereka belajar secara mandiri dalam membaca, menulis menghitung bisa dilakukan dengan membuat aplikasi media pembelajaran M3 (membaca, menulis, menghitung) yang mereka bisa akses di smartphone, dengan media pembelajaran tersebut bisa memudahkan mereka dalam mengingat apa yang sudah mereka dengar dan lihat ketika mengakses media pembelajaran tersebut ketika bermain Smartphone.
\end{abstract}

Kata Kunci: Media Pembelajaran, Multimedia, Smartphone.

\begin{abstract}
Kindergarten Education (TK) is a form of early childhood education, namely children aged four to six years. The purpose of kindergarten education is to lay the foundation towards the development of attitudes, knowledge, skills and creativity needed by children to adjust to the environment and their subsequent development into a literacy and numeracy school. To develop basic abilities of early childhood in reading and reading required interesting methods and make children interested in learning, so many books are available in bookstores with various colors and interesting shapes, but sometimes they also need to hear how to pronounce and hear what they learn independently. To develop their interest in learning independently in reading, writing and counting can be done by creating an M3 learning media application (reading, writing, counting) that they can access on a smartphone, with this learning media can make it easier for them to remember what they have heard and seen when accessing these learning media when playing Smartphone.
\end{abstract}

Keywords: Learning Media, Multimedia, Smartphone.

\section{PENDAhUluan}

$\mathrm{P}$ endidikan Taman Kanak-Kanak (TK) merupakan salah satu bentuk Pendidikan anak usia dini. Pendidikan TK memiliki peran yang sangat penting untuk mengembangkan kepribadian anak serta mempersiapkan mereka untuk memasuki jenjang pendidikan selanjutnya. Dengan kata lain, Pendidikan usia dini Khususnya TK sangat mengutamakan pendidikan yang berpusat pada anak.

Tugas utama TK adalah mempersiapkan anak dengan memperkenalkan berbagai pengetahuan, sikap/perilaku, keterampilan dan intelektual agar dapat melakukan adaptasi dengan kegiatan belajar yang sesungguhnya di sekolah dasar. Tujuan pendidikan TK untuk meletakkan dasar ke arah perkembangan sikap, pengetahuan, keterampilan dan daya cipta yang di perlukan anak untuk menyesuaikan diri dengan lingkungan dan perkembangan selanjutnya berubah menjadi sekolah baca tulis hitung dengan metode yang sering kali mengenyampingkan aspek - aspek perkembangan dan pertumbuhan anak.

Pengenalan pendidikan dasar untuk anak usia dibawah 5 tahun memang harus lebih sabar untuk membuat mereka mau belajar, begitu banyak buku yang tersedia di toko buku dengan berbagai warna dan bentuk yang menarik, namun terkadang mereka juga butuh 
mendengar bagaimana cara mengucapkannya, oleh karenanya diperlukan metode belajar yang menarik diantaranya melaui Aplikasi media pembelajaran M3 (membaca, menghitung, dan menulis) berbasis android, melalui media tersebut bisa memudahkan mereka dalam mengingat apa yang sudah mereka dengar dan lihat sehingga mereka bisa megucapkan dan mudah memahami apa yang mereka pelajari.

\section{STUDI PUSTAKA}

\section{A. Taman Kanak- Kanak (TK)}

Brewer (2007) dikutip dari maryatun (2017) Taman kanak sering juga disebut prasekolah, yaitu sekolah yang sesuai dengan karakteristik dan kebutuhan anak usia $4-6$ tahun. [1]

\section{B. Media}

Media merupakan suatu alat atau sarana sebagai perantara untuk menyampaikan bahan pelajaran dari guru kepada anak didik. Adapun indikator-indikator pengetahuan tentang media pendidikan yang harus dukuasai oleh seorang guru ialah : (1) mengetahui ciriciri umum media pendidikan, (2) mengetahui cara memilih dan mempersiapkan media pendidikan sederhana seperti gambar, peta dan sejenisnya, (3) mengetahui cara-cara menggunakan media pendidikan pada proses belajar mengajar, dan, (4) mengetahui cara menyesuaikan media pendidikan yang dipakai dengan bahan pelajaran yang diajarkan [2].

\section{Bahasa Adobe Flash Profesional CS6}

Adobe Flash Profesional CS6 adalah sebuah program animasi yang telah banyak di gunakan oleh para animator untuk menghasilakan animasi yang profesional. Di antara program-program animasi, program Adobe Flash Profesional CS6 merupakan program yang paling fleksibel dalam pembuatan animasi, seperti animasi interaktif, Game, Company Profile, Persentasi, Move, E-card dan Animasi yang di gunakan dalam situs web [3].

\section{Storyboard}

Storyboard adalah sebuah outline atau draft dari sebuah produksi berupa gambar - gambar yang beruntun.

\section{METODE PENELITIAN}

\section{A. Perancangan}

Secara umum perancangan pembuatan media pembelajaran dapat di lihat pada Gambar 1 .

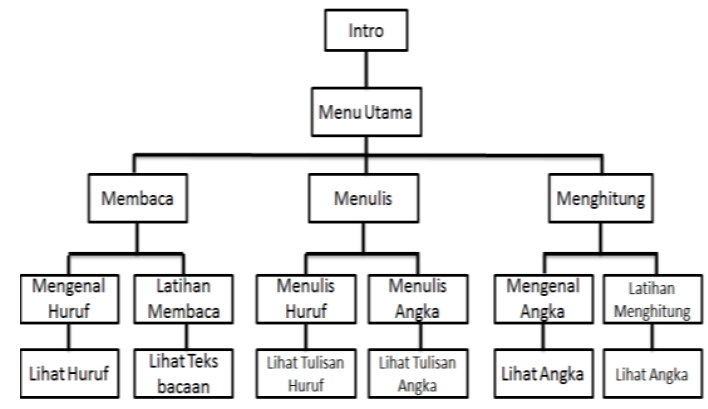

Gambar 1. Struktur Menu StroryBoard

Pembuatan media pembelajaran dibuat berdasarkan beberapa scene storyboard, rancangan scene storyboard yang dibuat dapat dilihat dari Gambar 2 sampai dengan Gambar 3:

\section{1) Scene pembuka}

Rancangan scene pembuka merupakan user interface yang pertama kali ditampilkan ketika aplikasi dibuka.

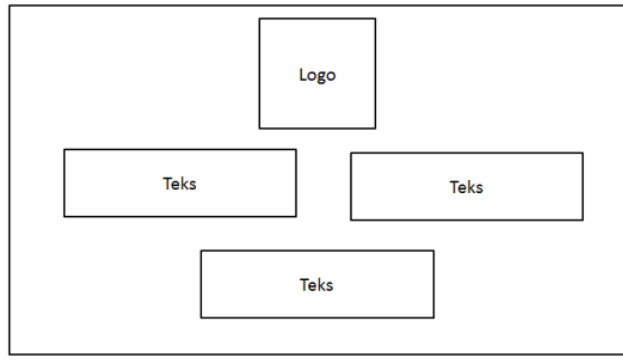

Gambar 2. Scene Pembuka

2) Scene menu utama

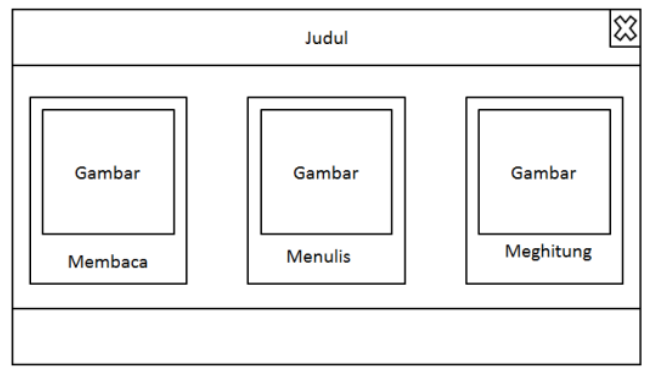

Gambar 3. Scene Menu Utama

3) Scene membaca

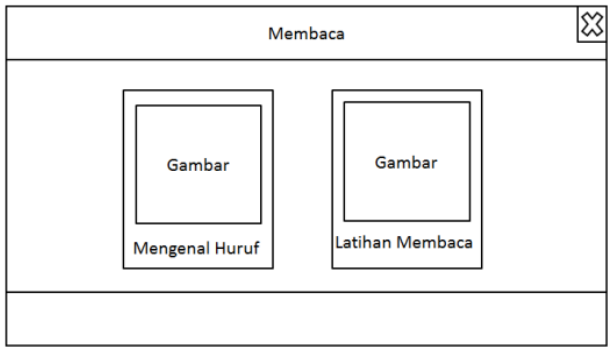

Gambar 4. Scene Menu Utama 
Fahrurrozi, Kharisma dan Khairunnazri - Media Pembelajaran M3 (Membaca, Menulis, Menghitung) Berbasis Multimedia Untuk Anak Usia Dini

4) Scene menulis

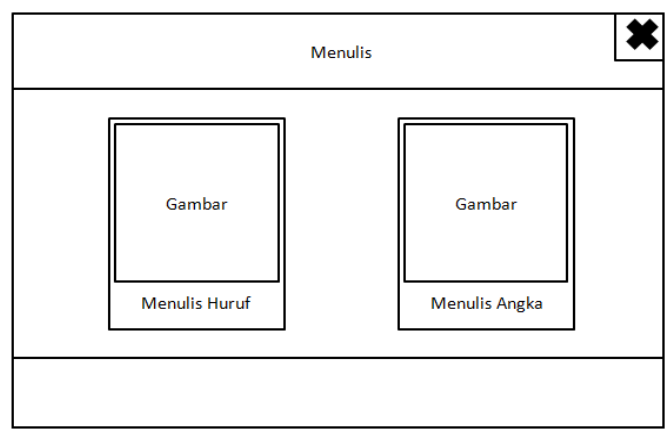

Gambar 5. Scene Menu Utama

5) Scene menghitung

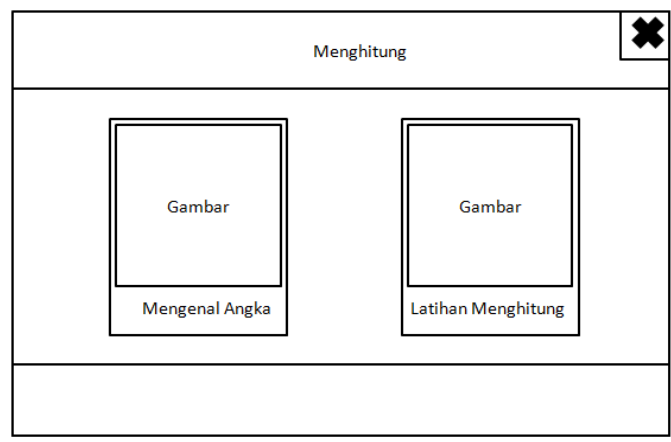

Gambar 6. Scene Menu Utama

6) Scene mengenal huruf

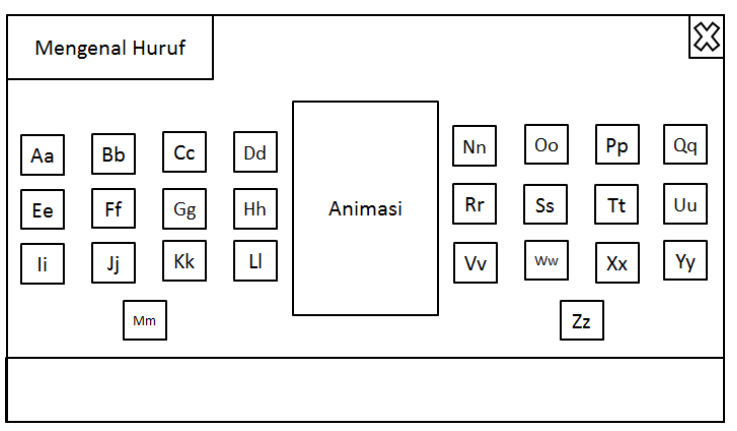

Gambar 7. Scene Menu Utama

7) Scene menulis huruf

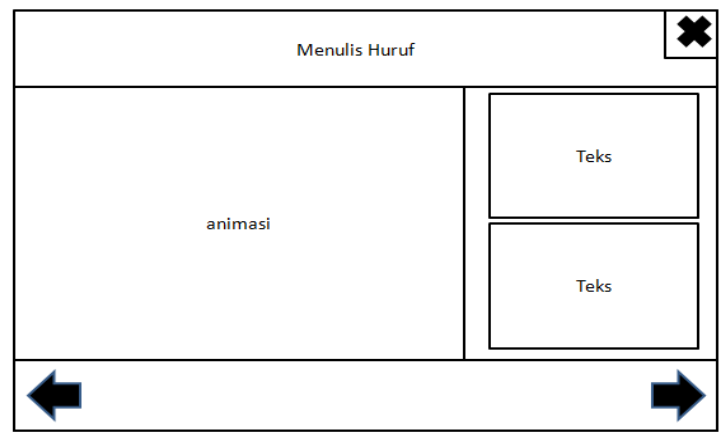

Gambar 8. Scene Menu Utama
8) Scene latihan membaca

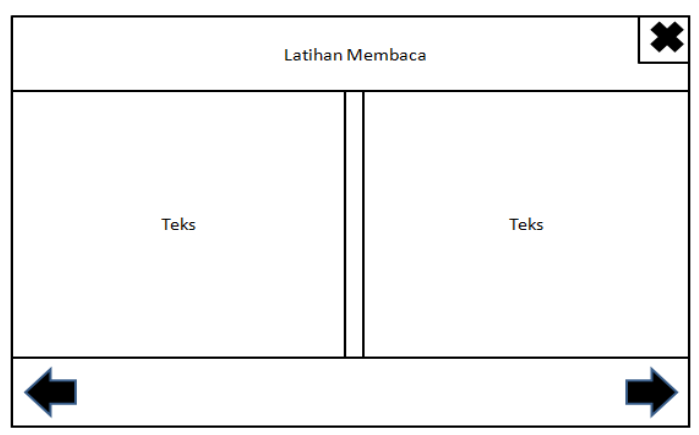

Gambar 9. Scene Menu Utama

9) Scene mengenal angka

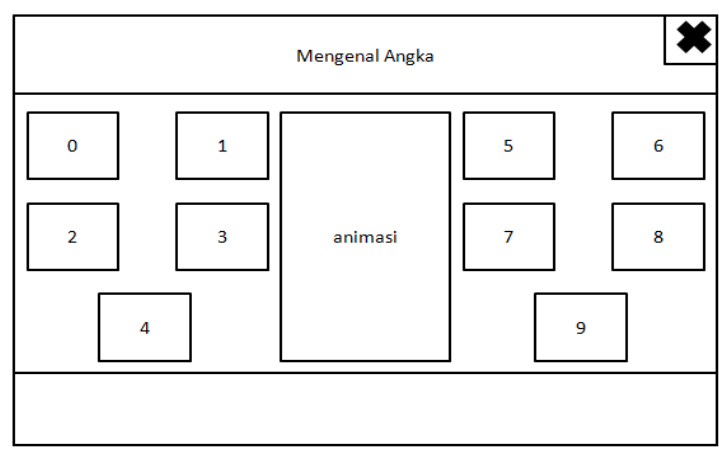

Gambar 10. Scene Menu Utama

10) Scene menulis angka

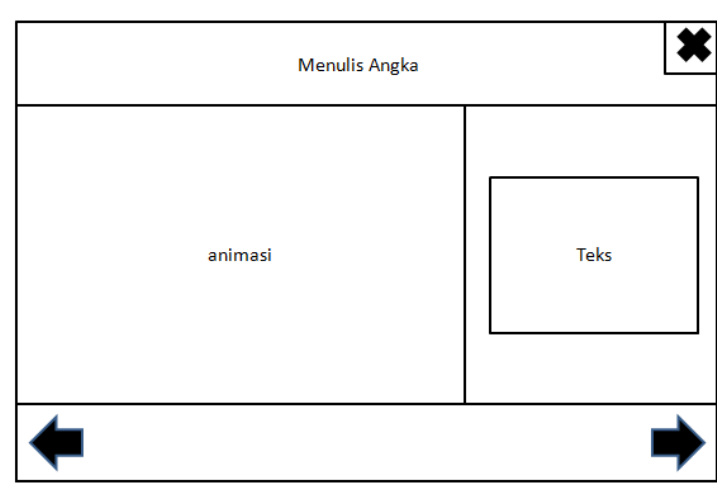

Gambar 11. Scene Menu Utama

11) Scene latihan menghitung

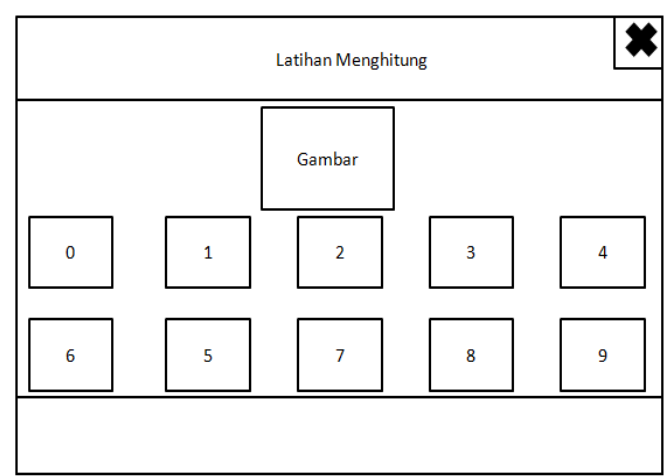

Gambar 12. Scene Menu Utama 


\section{2) Scene keluar}

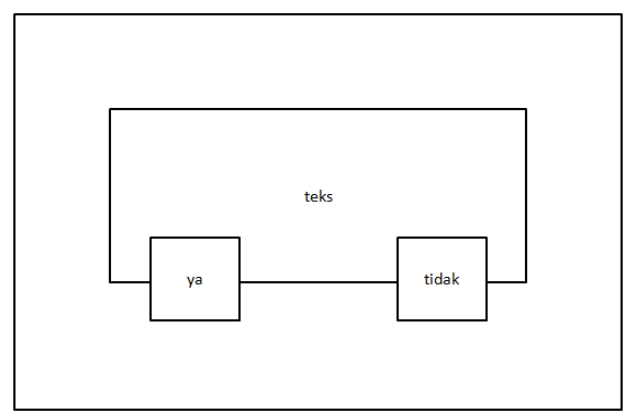

Gambar 13. Scene Keluar

\section{HASIL DAN PEMBAHASAN}

Berdasarkan rancangan dan kebutuhan yang telah dibuat dalam aplikasi media pembelajaran di diantaranya :

\section{A. Tampilan pembuka}

Animasi yang akan berjalan ketika pertama kali aplikasi dibuka sebelum masuk ke tampilan menu utama.

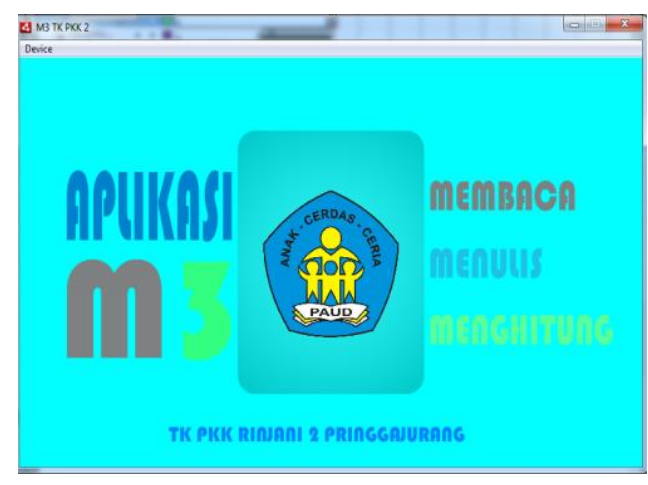

Gambar 14. Tampilan awal program

\section{B. Tampilan Menu Utama}

Menu utama terdiri dari tiga menu utama untuk memilih materi pembelajaran yang terdiri dari menu membaca, menulis, dan menghitung.

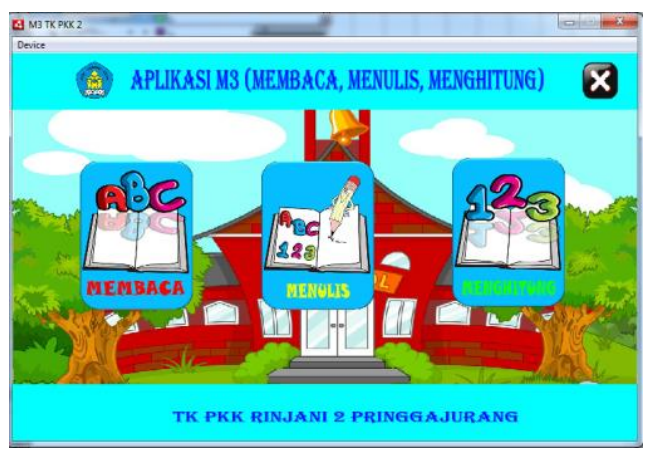

Gambar 15. Tampilan menu utama

\section{Tampilan menu membaca}

Menu membaca meiliki dua menu pilihan yaitu : a. menu mengenal huruf sebagai tombol menuju menu pengenalan huruf. $b$. menu latihan membaca sebagai tombol menuju menu latihan membaca.

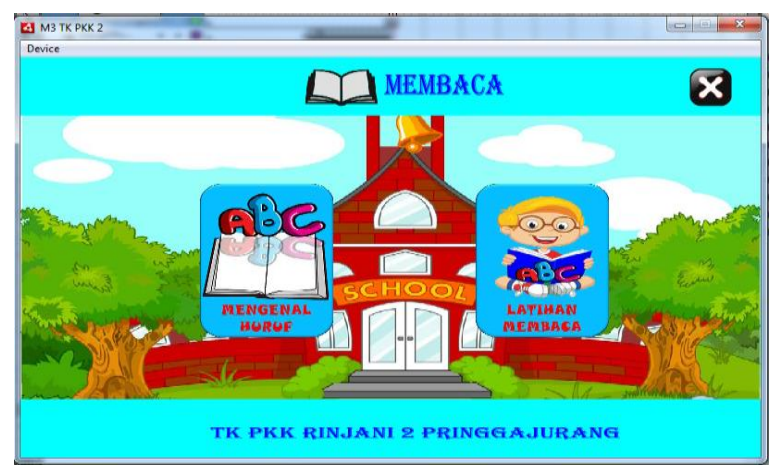

Gambar 16 Tampilan Menu Membaca

\section{Tampilan menu menulis}

Menu menulis mempunyai dua pilihan menu yaitu : a. menu menulis huruf sebagai tombol menuju Scene Menulis huruf. b. menu menulis angka sebagai tombol menuju menu Menulis Angka.

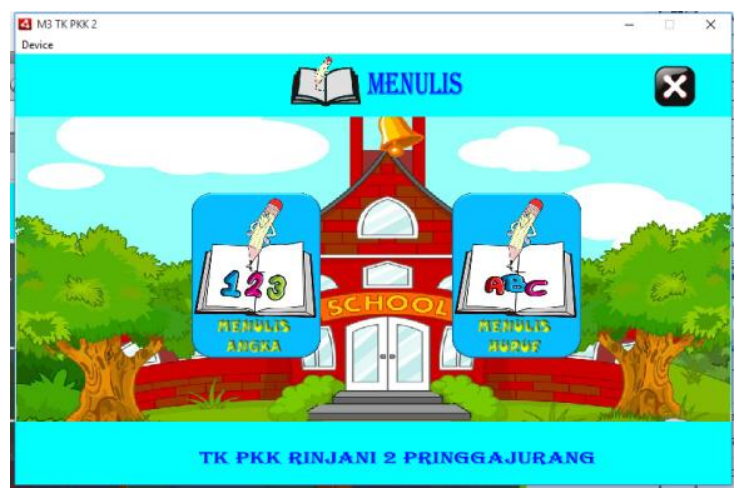

Gambar 17. Tampilan Menu Menulis

\section{E. Tampilan menu menghitung}

Menu menghitung mempunyai dua menu pilihan yaitu : a. menu mengenal angka sebagai tombol menuju Scene Mengenal angka. b.menu latihan menghitung sebagai tombol menuju menu latihan menghitung.

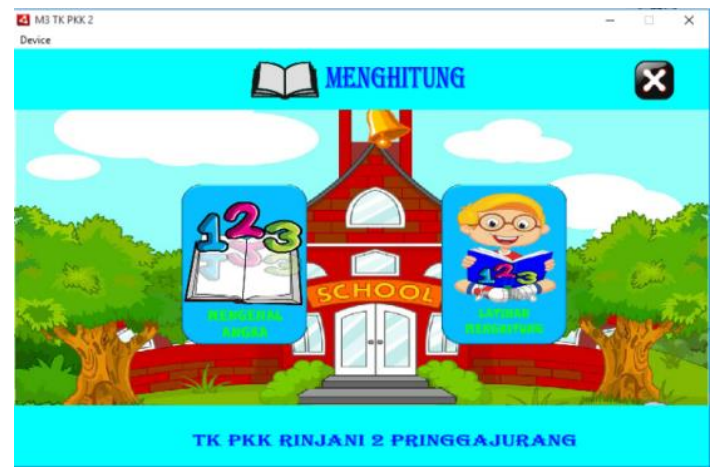

Gambar 18. Tampilan Menu Menghitung 


\section{F. Tampilan menu mengenal huruf}

Menu mengenal huruf berfungsi mengenali huruf alfabet beserta pengucapannya. Tombol " $\mathrm{X}$ " yang bergambar berfungsi kembali ke sub menu membaca dan tombol A-Z menampilkan tulisan dari alfabet beserta pengucapan dari huruf yang dipilih.

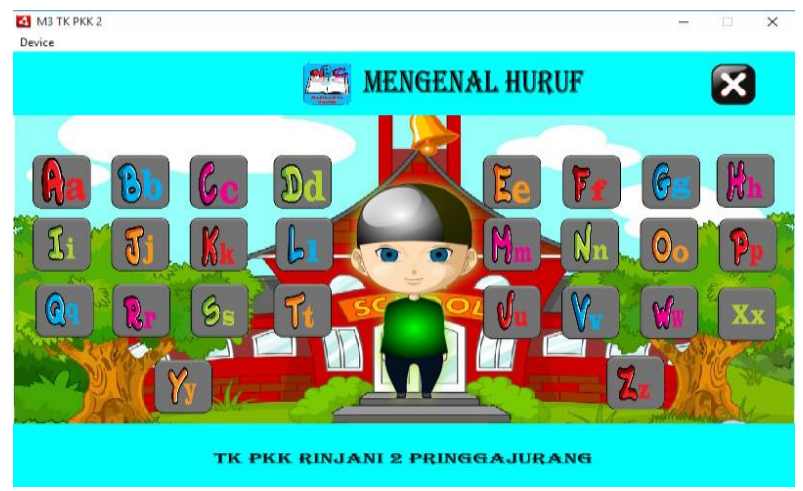

Gambar 19. Tampilan Mengenal Huruf

\section{G. Tampilan menu menulis huruf}

Menu menulis huruf menyediakan latihan cara menulis huruf. Tombol " $\mathrm{X}$ " berfungsi untuk kembali ke sub menu menulis, Tombol " $<$ " untuk melihat cara menulis huruf sebelumnya, dan Tombol ">" untuk melihat cara menulis huruf selanjutnya.

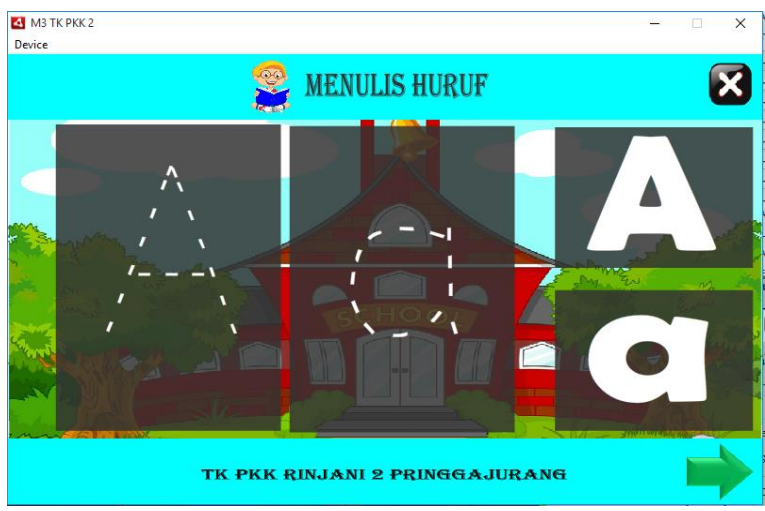

Gambar 20. Tampilan Menulis Huruf

\section{H. Tampilan menu latihan membaca}

Menu latihan membaca menampilkan teks latihan membaca. Tombol "X" berfungsi untuk kembali ke sub menu membaca, Tombol "<" untuk melihat Latihan Membaca sebelumnya, dan Tombol ">" untuk melihat Latihan Membaca selanjutnya.

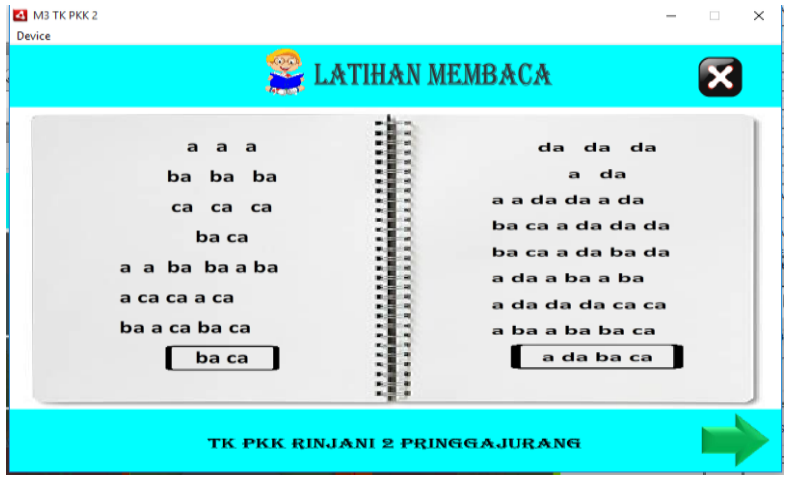

Gambar 21. Tampilan Membaca

\section{Tampilan menu mengenal angka}

Menu mengenal angka berfungsi mengenali angka beserta pengucapannya, Tombol " $\mathrm{X}$ " berfungsi kembali ke sub menu menghitung dan Tombol 0-9 menampilkan tulisan dari angka beserta pengucapan dari angka yang telah dipilih.

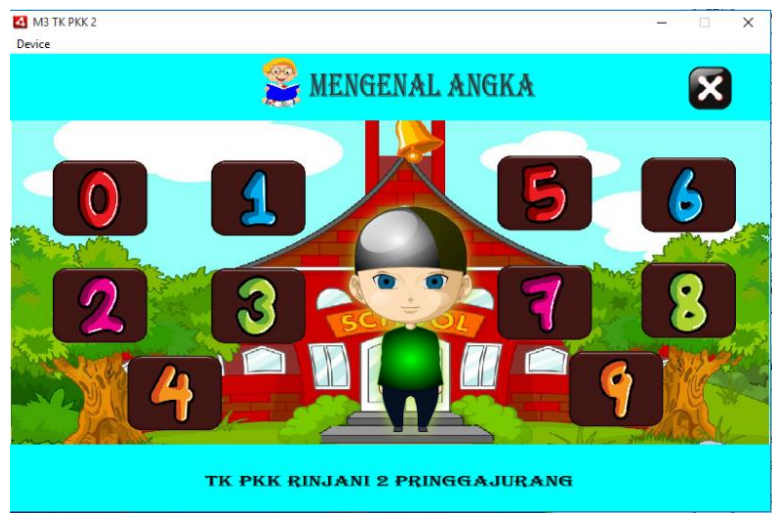

Gambar 22. Tampilan Mengenal Angka

\section{K. Tampilan menu menulis angka}

Menu menulis angka menyediakan dan menampilkan teks cara menulis angka. Tombol "X" berfungsi untuk kembali ke sub menu menulis, Tombol " $<$ " untuk melihat cara menulis angka sebelumnya, dan Tombol "> " untuk melihat cara menulis angka selanjutnya.

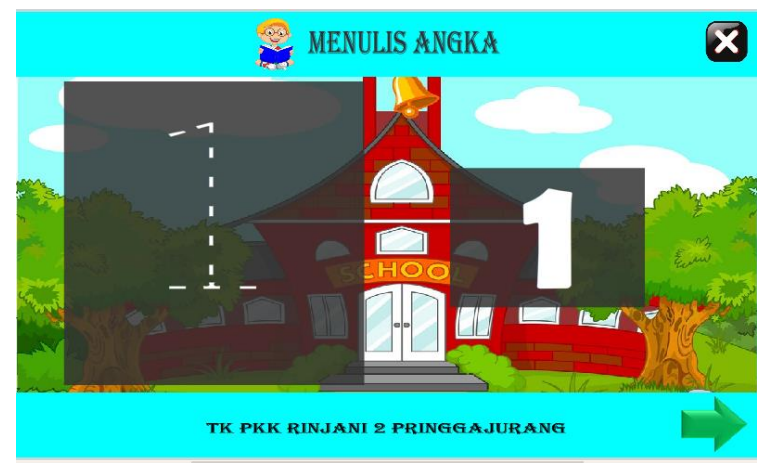

Gambar 23. Tampilan Menulis Angka 


\section{Tampilan menu latihan menghitung}

Menu latihan Menghitung memiliki deskripsi dimana Tombol " $X$ " berfungsi untuk kembali ke sub menu membaca dan Tombol 0-9 menampilkan tulisan dari angka beserta suara benar jika gambar sesuai dengan angka yang dipilih dan otomatis ke scane selanjutnya, dan suara salah apabila gambar dengan angka yang dipilih tidak sesuai.

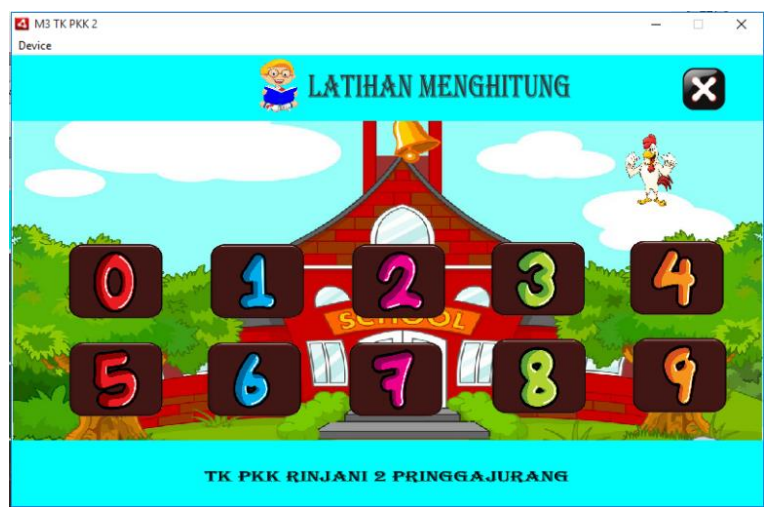

Gambar 24. Tampilan Latihan Menghitung

\section{K. Tampilan menu keluar}

Menu keluar berfungsi sebagai menu untuk keluar dari aplikasi. Ketika tombol menu keluar ditekan maka akan menampilkan dua pilihan yaitu tombol "ya" berfungsi keluar dari aplikasi dan tombol "tidak" berfungsi untuk kembali ke dalam aplikasi.

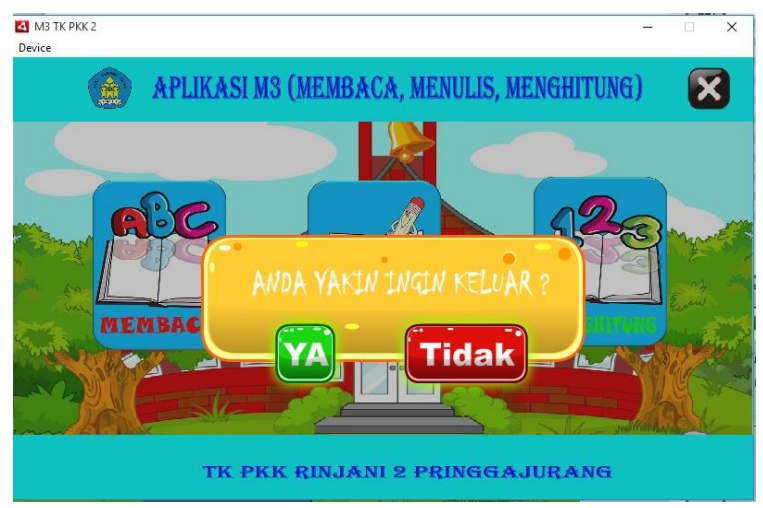

Gambar 25. Tampilan Keluar

\section{KESIMPULAN}

Media pembelajaran ini dapat menjadi media alternatif pembelajaran berbasis teknologi khususnya bagi siswa/siswi TK sederajat untuk meningkatkan semangat belajar bagi anak usia dini.

\section{DAFTAR PUSTAKA}

[1] Maryatun, I.K., "Pengembangan Tema Pembelajaran Untuk Taman Kanak-Kanak", Jurnal Pendidikan Anak, Volume 6, Edisi 1,FIP UNY, Yogyakarta, 2017

[2] Rasyid, I.K.S. \& Rohani," Manfaat Media Dalam Pembelajaran", AXIOM , Vol VII, No. I, P-ISSN : 2087 8249, 2018

[3] Andi, P., \& Syafii. M., " Kolaborasi Flash, Dreamweaver dan PHP. Malang” ANDI, Yogyakarta.2004 